\title{
PENGEMBANGAN INOVASI PRODUK KEUANGAN DAN PERBANKAN SYARIAH DALAM MEMPERTAHANKAN DAN MENINGKATKAN KEPUASAN NASABAH
}

\author{
Ferlangga Al Yozika ${ }^{1)}$, Nurul Khalifah ${ }^{2)}$ \\ Sekolah Tinggi Ilmu Ekonomi AAS Surakarta, Jawa Tengah \\ Email: ferlangga.stieaas@gmail.com
}

\begin{abstract}
Abstrak: Tujuan penelitian ini adalah bagaimana pengembangan inovasi produk keuangan dan perbankkan syariah dalam rangka untuk mempertahankan dan meningkatkan kepuasan nasabah atau konsumen yang telah ada serta untuk meningkatkan perluasan pasar yang masih terbuka lebar bagi kemajuan keuangan dan perbankan syariah di Indonesia. Metode yang digunakan dengan metode literasi dari berbagai sumber-sumber yang dapat dipercaya, seperti jurnal-jurnal penelitian sebelumnya, buku, dan lain sebagainya. Hasil penelitian menunjukkan bahwa pengembangan inovasi produk perbankan syariah salah satunya adalah mengembangkan pembiayaan ke sektor korporasi dengan cara menerapkan 1) pembiayaan sindikasi, yakni pembiayaaan yang diberikan kepada satu mudharib atau debitur oleh bankbank yang tergabung dalam satu kerjasama (musyarakah). 2) Inovasi dengan Trade Finance, fasilitas yang diberikan untuk membiayai kegiatan perdagangan debitur yang berkaitan dengan transaksi perdagangan luar negeri (ekspor-impor) maupun dalam negeri (jual beli). 3) Produk pengelolaan kas. 4) Pembiayaan Start up, adalah usaha dengan menggunakan basis teknologi informasi untuk produknya. 5) Business Development, yaitu salah satu fungsi manajemen perusahaan dalam upaya untuk mengembangkan bisnis yang dimiliki oleh perusahaan.
\end{abstract}

Kata kunci: inovasi produk, keuangan dan perbankan syariah, kepuasan nasabah

\begin{abstract}
The purpose of this research is how to develop the innovation of financial products and shariah bank in order to maintain and improve the satisfaction of existing customers or consumers and to increase market expansion that is still wide open for the advancement of finance and sharia banking in Indonesia. Methods used with literacy methods from various reliable sources, such as previous research journals, books, and so forth. The result of the research shows that the development of innovation of sharia banking product is one of them is to develop financing to the corporate sector by applying 1) syndicated financing, ie funding given to one mudharib or debtor by banks joined in a cooperation (musyarakah). 2) Innovation with Trade Finance, facilities provided to finance debtor trading activities related to foreign trade transactions (export-import) or domestic (buying and selling). 3) cash management products. 4) Financing Start up, is a business by using information technology base for its products. 5) Business Development, which is one of the corporate management functions in an effort to develop a business owned by the company.
\end{abstract}

Keywords: product innovation, finance and sharia banking, customer satisfaction

\section{PENDAHULUAN}

Setiap usaha perlu melakukan suatu terobosan secara terus menerus agar konsumen tidak merasa jenuh dengan produk yang sudah sering dikonsumsinya tersebut. Selain itu setiap pengusaha juga harus sadar, di samping masalah atau problem kejenuhan, juga yang 
tidak kalah menakutkan dan perlu selalu dijadikan tantangan adalah pesaing itu sendiri. Oleh karena itu, perlu senantiasa melakukan inovasi produk-produk yang diproduksi dan yang dipasarkan. Industri keuangan tak lain juga ikut mengalami hal tersebut yaitu usaha di dunia perbakkan, terutama perbankan syariah bila dibandingkan dengan perbankan konvensional. Perbankan konvensional sudah lama memerankan perannya sebagai lembaga keuangan yang melayani masyarakat Indonesia sudah sangat lama bila dibandingkan dengan perbankan syariah. Sehingga mau tidak mau perbankan syariah harus lebih aktif lagi di dalam melakukan inovasi produk jika ingin memeiliki pangsa pasar yang lebih banyak sekaligus berangsurangsur mampu memenangi persaingan meskipun jika diprediksi membutuhkan waktu yang sangat lama. Sebagaimana yang dikemukakan oleh Tho'in (2017), "to gain confidence, banks must be able to work professionally as customers expect from financial, in terms of service, and marketing strategies to be well managed, as well as to be more creative in generating new products desired by the public or customers". Artinya bahwa untuk mendapatkan kepercayaan, bank harus dapat bekerja secara profesional seperti yang diharapkan oleh pelanggan mulai dari segi finansial, dalam hal pelayanan, dan strategi pemasaran yang harus dikelola dengan baik, serta perbankan juga harus lebih kreatif dalam menghasilkan produk baru yang diinginkan publik atau pelanggan, agar eksistensi lembaga ini terus dapat dipertahankan di tengah persaingan.

Dengan demikian, bank syariah yang mau mengembangan inovasi produknya yang akan mampu bertahan dari sengitnya persaingan usaha dilembaga keuangan, serta yang akan mampu mempertahankan nasabahnya yang sudah ada sebelumnya, serta mampu mewujudkan harapan-harapan dan kebutuhan konsumen atau nasabahnya. Karena kepuasan konsumen akan tercapai apabila kualitas produk dan jasa yang diberikan sesuai dengan kebutuhannya. Dengan demikian perusahaan tersebut memiliki peluang lebih besar untuk tumbuh dan berkembang dalam jangka panjang dibanding perusahaanperusahaan lain yang hanya mengutamakan keuntungan semata tanpa menjaga dan mempertahankan kualitas produk dan jasa yang dihasilkannya (Tho'in, 2011). Jadi bank syariah bertugas lebih keras dalam mewujudkan produk dan jasa yang berkualitas serta melakukan pengembangan inovasi produk secara terus menerus.

Oleh karena itu, dalam penelitian ini akan mencoba melihat bagaimana pengembangan inovasi produk keuangan dan perbankkan syariah dalam rangka untuk mempertahankan dan meningkatkan kepuasan nasabah atau konsumen yang telah ada serta untuk meningkatkan perluasan pasar yang masih terbuka lebar bagi kemajuan keuangan dan perbankan syariah di Indonesia.

\section{KAJIAN TEORI}

\section{A. Inovasi Produk}

Menurut UU No. 19 Tahun 2002, inovasi adalah kegiatan penelitian, pengembangan, dan atau pun perekayasaan yang dilakukan dengan tujuan melakukan pengembangan penerapan praktis nilai dan konteks ilmu pengetahuan yang baru, atau pun cara baru untuk menerapkan ilmu pengetahuan dan teknologi yang sudah ada ke dalam 
produk atau pun proses produksinya. Sedangkan menurut Kuniyoshi Urabe (1998), inovasi merupakan setiap kegiatan yang tidak bisa dihasilkan dengan satu kali pukul, melainkan suatu proses yang panjang dan kumulatif, meliputi banyak proses pengambilan keputusan, mulai dari penemuan gagasan hingga ke implementasian nya di pasar.

Inovasi produk keuangan dan perbankan syariah merupakan pokok utama dalam pengembangan industri perbankan syariah, tentunya pengembangan harus didukung dengan kompetensi sumber daya manusia yang selain handal tetap berpegang teguh dengan prinsip-prinsip syariah (Tho'in, 2016). Bank-bank syariah harus memiliki produk inovatif yang semakin beragam agar bisa berkembang dengan baik. Inovasi juga harus dilakukan agar produk bank syariah tidak monoton dan dominan dengan akad tertentu di tengah bervarisanya kebutuhan bisnis masyarakat. Oleh karena itu, Otoritas Jasa Keuangan (OJK) terus mendorong pelaku industri keuangan syariah untuk terus berinovasi demi memenuhi kebutuhan masyarakat. OJK pun memaparkan beberapa inovasi produk yang dapat dilakukan oleh lembaga keuangan syariah, sebagaimana termuat dalam Roadmap Pengembangan Keuangan Syariah 2017-2019 www.ojk.go.id/.../syariah/.../RoadmapPengembangan-Keuangan-Syariah-Indonesia-.).

Menurut Respati (2017), perbankan syariah diharapkan mampu menciptakan outlet investasi bagi nasabah, khususnya kalangan menengah ke atas. Selain itu, bank syariah juga diharapkan dapat menambah variasi produk pembiayaan mikro, mengembangkan produk pembiayaan korporasi, trade finance, produk pengelolaan kas, pembiayaan bagi start up, serta produk pembiayaan untuk pembangunan infrastruktur. Sebagai contoh variasi produk pembiayaan mikro, contoh studi kasus di BNI Syariah ada 3 jenis yaitu rahn mikro, mikro 3 IB Hasanah, dan mikro 2 IB Hasanah. Masing-masing menyediakan plafond yang berbeda-beda. Jika anda hanya ingin pinjam uang Rp 500.000,- atau Rp 1.000.000,- saja maka bisa menggunakan pembiayaan Rahn Mikro, jika lebih tinggi maka bisa menggunakan produk lainnya. Pembiayaan rahn mikro, dimana dapat mengajukan pinjaman dana melalui pembiayaan ini mulai dari Rp. 500.000,- hingga Rp. 50.000.000,dengan pilihan Jangka Waktu 3 bulan, 6 bulan, 9 bulan atau 12 bulan (tidak dapat diperpanjang). Sedangkan Pembiayaan Mikro 3 iB Hasanah, dana yang dapat di pinjam melalui pembiayaan mulai dari >Rp. 50.000.000,- hingga Rp. 500.000.000,-. Silahkan anda memilih jangka waktu sesuai kebutuhan dan kemampuan mulai 6 bulan hingga 60 bulan. Dan Pembiayaan Mikro 2 IB Hasanah, yaitu pembiayaan mulai dari Rp. 5.000.000 hingga Rp. 50.000.000,- Jangka Waktu Pembiayaan mulai 6 bulan hingga 36 bulan.

\section{B. Kepuasan Nasabah}

Zulganef dalam Utami dan Aryani (2004 menyebutkan bahwa kepuasan pelanggan itu dipergunakan sebagai evaluasi terhadap pelayanan. Namun selain itu ada juga yang menggambarkan kepuasan pelanggan sebagai selisih dari harapan sebelum mengkonsumsi dengan kondisi aktual produk yang dikonsumsi. Tujuan dari suatu bisnis adalah untuk menciptakan konsumen merasa puas. Terciptanya kepuasan dapat memberikan manfaat 
dan keuntungan bagi perusahaan (Tjiptono, 2005). Karenanya, setiap perusahaan harus menempatkan orientasi pada kepuasan konsumen sebagai tujuan utamanya.

Menurut Umar (1999), kepuasan terdiri dari dua macam, yaitu kepuasan fungsional dan kepuasan psikologis. Kepuasan fungsional merupakan kepuasan yang diperoleh dari fungsi suatu produk yang dimanfaatkan. Sedangkan kepuasan psikologis merupakan kepuasan yang diperoleh dari atribut yang bersifat tidak berwujud dari suatu produk, misalnya menaikkan gengsi, menciptakan pribadi tertentu. Menurut Kotler (1995), kepuasan pelanggan adalah tingkat perasaan seseorang setelah membandingkan kinerja yang dirasakan dengan harapannya. Jadi tingkat kepuasan adalah fungsi perbedaan antara kinerja yang dirasakan dengan harapannya. Kalau kinerja di bawah harapan, pelanggan kecewa. Kalau kinerja sesuai harapan, pelanggan puas. Dan kalau kinerja melebihi harapan, pelanggan sangat puas, senang, atau gembira. Kepuasan pelanggan dapat diketahui setelah pelanggan/konsumen menggunakan produk dan jasa pelayanan.

\section{METODE PENELITIAN}

Ruang lingkup penelitian ini ingin mengetahui bagaimana pengembangan inovasi produk keuangan dan perbankan yang ada di bank syariah. Metode dalam makalah ini menggunakan metode study literature, dengan memaparkan teori yang berhubungan dengan permasalahan yang sedang diteliti yaitu mengenai pengembangan inovasi produk yang dilakukan bank syariah dalam rangka untuk mempertahankan dan meningkatkan kepuasan nasabah atau konsumen yang telah ada serta untuk meningkatkan perluasan pasar yang masih terbuka lebar bagi kemajuan keuangan dan perbankan syariah di Indonesia, yang diperoleh dari jurnal, buku dokumentasi, dan internet.

\section{PEMBAHASAN}

\section{Pengembangan Inovasi Produk Perbankan Syariah}

Untuk mengembangkan produk pembiayaan korporasi, banyak strategi yang bisa dilakukan untuk meningkatkan asset perbankan syariah. Salah satunya adalah mengembangkan pembiayaan ke sektor korporasi. Pembiayaan ke korporasi yang relatif besar akan memberikan peluang keuntungan yang relatif besar, namun juga memiliki risiko yang cukup besar juga, maka salah satu strategi yang bisa dilakukan perbankan syariah agar lebih aman memasuki sektor korporasi dengan cara menerapkan pembiayaan sindikasi, yakni pembiayaaan yang diberikan kepada satu mudharib atau debitur oleh bank-bank yang tergabung dalam satu kerjasama (musyarakah).

Sindikasi dapat dilakukan antara bank syariah dan bank konvensional. Beberapa waktu yang lalu bank konvensional pernah mengajak bank syariah untuk ikut dalam sebuah pembiayaan sindikasi di mana leader-nya adalah konvensional. Hal tersebut boleh saja dilakukan apabila sepanjang sindikasi tersebut tidak melanggar prinsip-prinsip syariah dengan pemisahan dan pembatasan aspek tertentu. Bagi perbankan syariah, pembiayaan sindikasi tidak hanya berperan untuk meningkatkan asset perbankan syariah dan menjaga likuiditas akan tetapi juga sebagai bentuk kontribusi langsung perbankan syariah dalam pembangunan 
nasional di Indonesia. Dengan melakukan serta mengembangkan pembiayaan sindikasi inilah perbankan syariah di Indonesia bisa berperan membiayai proyek-proyek infrastuktur dan korporasi berskala besar.

Pengertian Pembiayaan Sindikasi itu sendiri merupakan pembiayaan yang diberikan oleh beberapa kreditur sindikasi (atau shahibul mal), yang biasanya terdiri dari bank-bank dan/atau lembaga-lembaga keuangan lainnya kepada debitur (atau mudharib), yang biasanya berbentuk badan hukum untuk membiayai satu atau beberapa proyek usaha. Pembiayaan sindikasi tersebut diberikan secara sinergis (syirkah) sesama bank syariah, karena jumlah pembiayaan yang dibutuhkan untuk membiayai proyek korporasi tersebut sangat besar, sehingga sulit atau tidak mungkin dibiayai oleh kreditur tunggal. Sesuai dengan definisi tersebut, bahwa dalam pemberian pembiayaan sindikasi, jumlah pembiayaan akan terlalu besar apabila diberikan oleh satu bank saja.

Selanjutnya, inovasi dengan Trade Finance, Trade Finance adalah fasilitas yang diberikan untuk membiayai kegiatan perdagangan debitur yang berkaitan dengan transaksi perdagangan luar negeri (ekspor-impor) maupun dalam negeri (jual beli). Manfaat Trade Finance, yaitu untuk meningkatkan efisiensi pengelolaan modal kerja debitur melalui penyediaan fasilitas pembiayaan piutang dagang, persediaan barang jadi atau bahan baku dan atau fasilitas penundaan pembayaran kewajiban dalam rangka perdagangan, mengendalikan risiko-risiko yang terkait dengan transaksi perdagangan debitur, menyediakan alternatif pembiayaan dengan struktur biaya yang lebih kompetitif bagi debitur dibanding dengan menggunakan fasilitas kredit konvensional, meningkatkan kredibilitas debitur terhadap counter party, dan menyediakan sarana untuk menunjang kelancaran arus pembayaran transaksi debitur.

Setelah Trade Finance, ada produk pengelolaan kas. Pembentukan kas kecil harus ada nominal yang sudah harus dipastikan dalam saldo kas kecil. Nominal yang ditentukan harus sesuai dengan skala operasional perusahaan. Dalam produk pengelolaan kas, batas saldo minimal kas kecil dalam manajemen pengelolaan kas kecil itu diperbolehkan untuk diubah, akan tetapi kebijakan baru itu sebaiknya diumumkan kepada seluruh pihak yang terlibat didalam perusahaan. Pemberitahuan ini perlu diketahui dan dijadikan dasar pertimbangan bagi setiap departemen di perusahaan di dalam melakukan pemetaan akan dana atau pembelian barang.

Kemudian setelah produk pengelolaan kas, ada inovasi pengembangan produk keuangan dengan Pembiayaan Start Up, pada saat ini bisnis start up sedang diminati oleh kalangan IT. Start up adalah usaha dengan menggunakan basis teknologi informasi untuk produknya. Dalam pendanaan bisnisnya, seorang entepreneur start up memiliki cirinya masing-masing. Ada entepreneur start up yang menggunakan kemampuan dana milik sendiri, ada juga yang melakukan pinjaman dana modal kepada kreditur atau dana pihak bank untuk menjalankan usahanya.

Ada beberapa jenis pembiayaan start up yang perlu dipahami, diantaranya pembiayaan hutang (debt financing), yaitu jenis pembiayaan yang biasanya melakukan pinjaman atau kredit dengan tingkat suku bunga tertentu kepada lembaga tertentu atau kreditur. Dalam hal 
tersebut, lembaga yang biasanya dijadikan sebagai kreditur adalah bank atau perbankan yang bersangkutan. Untuk mengajukan pinjaman di bank, seorang entepreneur harus membuat proposal bisnis yang berisi laporan usahanya dan kebutuhan pendanaan yang sedang diperlukan untuk bisnis start up yang sedang dijalaninya. Pihak kreditur biasanya melihat kondisi usahanya berdasarkan laporan keuangan usaha yang dijalaninya pada periode tertentu. Pada saat bank memberikan pinjaman, kreditur atau pihak bank akan menetapkan suku bunga dan tanggal jatuh tempo untuk pengembalian pinjaman. Jenis pembiayaan start up ini jarang diambil oleh entepreneur start up karena resiko yang diambil terlalu besar untuk mereka.

Jenis pembiayaan start up yang kedua yaitu pembiayaan investor (investment financing/equity financing), Pembiayaan investor adalah jenis pembiayaan yang dilakukan oleh pihak swasta atau investor terhadap suatu usaha. Pembiayaan jenis ini bisa dimulai dari skala kecil yaitu melalui keluarga atau teman, hingga ke skala besar yaitu melalui investor besar. Dalam pembiayaan ini, entepreneur start up dan investor akan menyepakati pendanaan untuk periode tertentu. Investor nantinya akan bertindak sebagai pemegang saham. Dana dari investor berbeda dengan dana pinjaman dari bank. Seorang entepreneur akan menggunakan dana dari investor untuk memutar usahanya. Pada periode tertentu, investor akan mendapatkan bagi hasil atau deviden dari keuntungan usaha yang dijalankan oleh entepreneur start up. Pembiayaan start up ini dipakai oleh banyak entepreneur start up, kemudian entepreneur akan mencari investor setelah usahanya sudah berjalan beberapa bulan dimulai.

Jenis pembiayaan start up yang ketiga yaitu pembiayaan sendiri (bootstraping), ialah pembiayaan yang dilakukan secara mandiri oleh entepreneur. Pembiayaan ini banyak dilakukan entrepreneur start up yang sedang memulai usahanya. Pembiayaan berasal dari tabungan pribadi entepreneur. Untuk melakukan pembiayaan mandiri, seorang entepreneur harus merencanakan kegiatan usahanya dengan benar. Untuk memulai bootstraping, seorang entepreneur biasanya akan mengevaluasi aset-aset pribadi dan tabungannya. Setelah itu, ia akan melakukan perancanaan keuangan dengan prinsip melakukan banyak hal dengan sedikit pengeluaran (doing more with less). Pendanaan pribadi biasanya tidak akan bertahan lama karena minimnya sumber daya. Seorang entepreneur start up mampu membuat perencanaan keuangan dan usahanya dengan baik, pengeluaran yang mereka lakukan akan kembali dengan hasil usaha yang mereka kerjakan.

Jenis pembiayaan start up yang keempat yaitu bantuan atau hibah (grant), ini adalah salah satu pembiayaan start up yang populer dan banyak dicari oleh entepreneur. Pada saat ini, baik pihak pemerintah ataupun swasta banyak mengeluarkan program bantuan dan hibah modal kepada entepreneur start up. Beberapa bantuan modal ini biasanya diberikan secara langsung, tetapi ada juga yang melalui sebuah kompetisi start up. Pada saat seorang entepreneur mengajukan bantuan modal, mereka dituntut membuat sebuah proposal yang berisi rancangan bisnis yang sedang dijalaninya, serta laporan keuangan bisnis dan rancangan pendanaan. Kelebihan lain dari jalur ini (bantuan dan hibah modal) selain mendapatkan bantuan modal usaha, entepreneur juga berkesempatan mendapatkan program inkubator bisnis dan mentoring dengan praktisi yang ada. Ini lah yang membuat entepreneur start up sangat minat terhadap pembiayaan melalui jalur bantuan modal atau hibah (grant). 
Kemudian untuk mengembangkan produk perbankan syariah selanjutnya ada Business Development, yaitu salah satu fungsi manajemen perusahaan dalam upaya untuk mengembangkan bisnis yang dimiliki oleh perusahaan. namun dalam pengertian yang lebih luas Business Development bukan hanya melakukan analisa bisnis yang ada pada saat ini tetapi juga bagaimana mengelola opportunity business yang ada menjadi sesuatu yang dapat dilakukan oleh perusahaan dengan menggunakan sebagian atau seluruh sumber daya yang dimilikinya. Banyak yang mengkaitkan Business Development dengan Marketing dengan menyatakan bahwa fungsi Business Development adalah merupakan upaya perusahaan untuk meningkatkan fungsi marketing dan bagimana melakukan penjualan, mencapai target penjualan, kemudian menindaklanjuti marketing program dan lain sebagainya terkait dengan permasalahan marketing. Akan tetapi fungsi-fungsi tersebut merupakan sebagian kecil dari fungsi Business Development, karena idealnya Business Development harus memiliki cakupan yang lebih luas hal ini terkait dengan pengembangan bisnis yang bukan hanya sekedar mengembangkan permasalahan marketing saja, tetapi lebih dari itu termasuk memilih bisnis apa yang paling cocok atau menguntungkan bagi perusahaan dan konsep seperti apa untuk dapat melaksanakan sebuah bisnis.

\section{SIMPULAN}

Pengembangan inovasi produk perbankan syariah salah satunya adalah mengembangkan pembiayaan ke sektor korporasi dengan cara menerapkan 1) pembiayaan sindikasi, yakni pembiayaaan yang diberikan kepada satu mudharib atau debitur oleh bankbank yang tergabung dalam satu kerjasama (musyarakah). 2) Inovasi dengan Trade Finance, fasilitas yang diberikan untuk membiayai kegiatan perdagangan debitur yang berkaitan dengan transaksi perdagangan luar negeri (ekspor-impor) maupun dalam negeri (jual beli). 3) Produk pengelolaan kas. 4) Pembiayaan Start up, adalah usaha dengan menggunakan basis teknologi informasi untuk produknya. 5) Business Development, yaitu salah satu fungsi manajemen perusahaan dalam upaya untuk mengembangkan bisnis yang dimiliki oleh perusahaan.

\section{SARAN}

Bank-bank syariah harus bangkit dan kreatif untuk inovatif, dalam konteks pengembangan produk perbankan syariah. Upaya ini mutlak dilakukan karena bank syariah akhir-akhir ini mengalami perlambatan pertumbuhan bahkan penurunan market share dibanding konvensional. Inovasi terhadap produk keuangan bank syariah harus terus dilakukan, agar perbankan syariah bisa tumbuh dan mampu bersaing dengan perbankan konvensional maupun lembaga keuangan lain. Inovasi produk juga sangat dibutuhkan dalam menghadapi perkembangan bisnis yang terus berubah seiring perkembangan zaman. 


\section{DAFTAR PUSTAKA}

Hudaya, Riandra Fata. (2011). Strategi Inovasi Produk PT. Bank Panin Syariah Tbk dalam Meningkatkan Daya Saing Antar Sesama Bank Syariah dan Bank Konvensional. Skripsi. Jakarta: UIN Syarif Hidayatullah.

Kotler, Philip. (1995). Manajemen Pemasaran Analisis, Perencanaan Implementasi dan Pengendalian. Jakarta: Salemba Empat.

Nursyanti, Reni. (2016). 3 Jenis Pembiayaan Mikro Bank BNI Syariah dan Syarat Lengkapnya.

Pasrizal, Himyar. 2013. Konsep Marketing dalam Inovasi Produk Perbankan Syariah. Jurnal, Vol. 02, No. 02.

Tho'in, M. (2017). Analysis Of Islamic Bank Customer's Satisfaction Using Importance Performance Analysis (IPA). ADRI International Journal Of Marketing and Entrepreneurship, 1(1), 42-48.

Tho'in, M. (2016). Kompetensi Sumber Daya Manusia Bank Syariah Berdasarkan PrinsipPrinsip Syariah Islam (Studi Kasus Pada BNI Syariah Surakarta). Jurnal Ilmiah Ekonomi Islam, 2(03).

Tho'in, M. (2011). Pengaruh Faktor-faktor Kualitas Jasa terhadap Kepuasan Nasabah di Baitul Mal Wat Tamwil (BMT) Tekun Karanggede Boyolali. MUQTASID Jurnal Ekonomi dan Perbankan Syariah, 2(1), 73-89.

Tjiptono, Fandy. (2005). Pemasaran Jasa. Jakarta: Bayu Media Publishing.

Ulum, Fahrur. (2014). Inovasi Produk Perbankan Syariah di Indonesia. Jurnal, Vo. 17, No. 1.

Umar, Husein. (1999). Metode Penelitian dan Aplikasi dalam Pemasaran. Jakarta: Gramedia Pustaka Utama.

Utami, Anggit dan Y, Anni Aryani, (2004). Pengaruh Faktor-Faktor Kualitas Jasa Terhadap Kepuasan Nasabah (Studi Kasus Di Bsm Cabang Surakarta). Fakultas Ekonomi UNS: Jurnal Akuntansi dan Bisnis Vol. 4.

Undang-Undang No. 19 Tahun 2002

Urabe, Kuniyoshi. Child, John. Kagono, Tadao. (1998) Innovation and Management : international comparisons. Walter de Gruyter, Berlin; New York.

William Baumol, et al. (2010). Good Capitalism, Bad Capitalism. Jakarta: Gramedia Pustaka Utama dan Ciputra University

www.infoperbankan.com/bni-syariah/3-jenis-produk-pembiayaan-mikro-dari-bank-bnisyariah.html?_e_pi_=7\%2CPAGE_ID10\%2C2081076429. Diunduh hari Senin, 9 Oktober 2017, pukul 10.15 WIB.

www.ojk.go.id/.../syariah/.../Roadmap-Pengembangan-Keuangan-Syariah-Indonesia-.)

Yogi, Respati. (2017). Ini Inovasi Produk yang Bisa Dilakukan Lembaga keuangan Syariah. http://kucintakeuangansyariah.com/ini-inovasi-produk-yang-bisa-dilakukan-lembagakeuangan-syariah/. Diunduh hari Senin, 9 Oktober 2017, pukul 10.05 WIB. 